\title{
OGRANIČENJA SLOBODE IZRAŽAVANJA U REPUBLICI HRVATSKOJ U ODNOSU NA MEĐUNARODNO PRAVO, S POSEBNIM OSVRTOM NA PRESUDE EUROPSKOG SUDA ${ }^{1}$
}

\author{
UDK: $342.727(497.5: 4-6 E U)$ \\ DOI: $10.31141 /$ zrpfs.2021.58.141.967 \\ Pregledni rad \\ Primljeno: 10. listopada 2020.
}

\begin{abstract}
Sloboda izražavanja misli bez sumnje je jedan od kamena temeljaca demokracije. Njezina pravna priroda kompleksna je, s obzirom na to da je ona istovremeno izvedenica i pravna konstrukcija. Naime, sloboda izražavanja misli jedan je od derivata slobode kao temeljne vrednote modernih pravnih sustava koji počivaju, jasno, na međunarodnom pravu ljudskih prava. I dok je sloboda apsolutna kategorija, sloboda izražavanja i neka druga prava to nisu.
\end{abstract}

Ključne riječi: sloboda izražavanja, ograničenja, Europski sud za ljudska prava, presude, Republika Hrvatska

\section{UVODNA NAPOMENA}

Odnos između apsolutne slobode misli i slobode njezina izražavanja izravno vodi zaključku da se sloboda izražavanja misli, za razliku od slobode kao temeljne vrednote, može i mora podvrgnuti ograničenjima u svrhu zaštite drugih prava i sloboda. To se u modernim demokratskim sustavima može izvršiti samo posredstvom zakonskih odredbi. Najvažniji međunarodnopravni akti koji određuju i jamče slobodu izražavanja misli, ali je istovremeno ograničavaju, jesu: Univerzalna deklaracija o ljudskim pravima, Međunarodni pakt o građanskim i političkim pravima te Europska konvencija za zaštitu ljudskih prava i temeljnih sloboda. ${ }^{2}$

U radu provjeravamo je li hrvatski pravni sustav u pogledu ograničenja slobode izražavanja normativno usklađen s međunarodnim pravom. Posebno razmatramo presude koje je Europski sud donio temeljem tužbi hrvatskih građana zbog kršenja

1 Ivana Mijić Vulinović, doktorica međunarodnog prava, Stručni suradnik Sveučilišta u Dubrovniku, Kućna adresa: Iva Vojnovića 31, 20000 Dubrovnik, e-mail: ivana.mijic@yahoo.com.

2 Odluka o objavi Opće deklaracije o ljudskim pravima, Narodne novine 12/2009-143. Ista slobodu mišljenja i izražavanja misli jamči člankom 19., dok je ograničava 12. i čl. 11. st. 2. Potonjima zapravo jamči pravo na zaštitu privatnog i obiteljskog života, ugleda i časti, te propisuje načelo nevinosti; međunarodni o građanskim i političkim pravima slobodu izražavanja misli jamči u čl. 19., dok je ograničava pojedinačno čl. 20. u kojem zabranjuje propagandu u korist rata kao i govor mržnje. 
slobode izražavanja koja je, prema tumačenjima domaćih nadležnih sudskih tijela, u spornim slučajevima podlijegala zakonskim ograničenjima.

\section{OGRANIČENJA SLOBODE IZRAŽAVANJA PREMA EUROPSKOJ KONVENCIJI ZA ZAŠTITU LJUDSKIH PRAVA I TEMELJNIH SLOBODA I PRAKSI EUROPSKOG SUDA ZA LJUDSKA PRAVA}

Iz odredbi Europske konvencije za zaštitu ljudskih prava i temeljnih sloboda, dodatno pojašnjene tumačenjem Europskog suda za ljudska prava, proizlazi i najpreciznije određenje slobode izražavanja. Naime, Konvencija u članku 10. propisuje sljedeće:

"(1) Svatko ima pravo na slobodu izražavanja. Ovo pravo uključuje slobodu mišljenja i slobodu primanja i prenošenja informacija i ideja, bez miješanja javne vlasti i bez obzira na granice. Ovaj članak ne sprječava države da zahtijevaju dozvole za rad od radio, televizijskih i filmskih kompanija.

(2) Kako ostvarivanje tih sloboda obuhvaća dužnosti i odgovornosti, ono može biti podvrgnuto formalnostima, uvjetima, ograničenjima ili kaznama propisanim zakonom, koji su u demokratskom društvu nužni radi interesa državne sigurnosti, teritorijalne cjelovitosti ili javnog reda i mira, radi sprječavanja nereda ili zločina, radi zaštite zdravlja ili morala, radi zaštite ugleda ili prava drugih, radi sprječavanja odavanja povjerljivih informacija ili radi očuvanja autoriteta i nepristranosti sudbene vlasti."

Dakle, stavkom 2. propisani su dopušteni razlozi za ograničenja slobode izražavanja, kao i demokratski standard prema kojemu se ista mogu odrediti samo putem zakonskih normi. Europski sud prilikom utvrđivanja je li došlo do povrede čl.10. Konvencije primjenjuje tzv. trodijelni test. On sam po sebi predstavlja demokratski standard kojim bi se trebale rukovoditi i države stranke pri utvrđivanju je li ili nije povrijeđena sloboda izražavanja. Test podrazumijeva sljedeće: (1.) Provjeru je li ograničenje slobode izražavanja propisano zakonom; (2.) Provjeru je li zakonsko ograničenje slobode izražavanja bilo motivirano zaštitom nekog od legitimnih ciljeva iz čl. 10. st. 2. Konvencije; (3.) Provjeru je li zakonsko ograničenje slobode izražavanja motivirano zaštitom nekog od legitimnih ciljeva iz čl. 10. Konvencije bilo neophodno u demokratskom društvu.

Sud pritom postavlja vrlo jasne kriterije za utvrđivanje te 'neophodnosti u demokratskom društvu', kojom bi se pri predmetima u svezi sa slobodom izražavanja trebali voditi i domaći sudovi. Kako bi miješanje države u nečiju slobodu izražavanja (u vidu zakonskog ograničenja, odluke javne vlasti, sudske kazne) bilo 'neophodno u demokratskom društvu', mora za to miješanje, odnosno ograničenje, postojati 'neodgodiva društvena potreba'. Nije dovoljno samo postojanje društvene potrebe, 
ona mora biti žurna. Ujedno, ograničenja moraju biti primjerena i razmjerna legitimnom cilju kojem služe.

V. Alaburić, između ostaloga, naročito izdvaja međunarodne demokratske standarde koji se odnose na ograničenje slobode izražavanja u svrhu zaštite autoriteta i nepristranosti sudova. ${ }^{3} \mathrm{U}$ pogledu navedenoga zapravo se 'na vagu' sa slobodom izražavanja stavlja pravo na pravično suđenje zaštićeno člankom 6. Konvencije.

Jedna od najvažnijih sastavnica slobode izražavanja jest sloboda medija (sloboda tiska). Prema tumačenjima Europskog suda za ljudska prava, novinari imaju veću slobodu izražavanja od ostalih; njihova sloboda izražavanja manje podliježe ograničenjima zbog značaja i uloge koju mediji imaju u demokratskom društvu. To je uloga javnog psa čuvara čiji je zadatak širiti informacije i ideje od javnog interesa. Realizirajući taj svoj zadatak, mediji omogućuju ostvarenje prava javnosti da zna (informacije i ideje od javnog interesa). Iz prakse Europskog suda iščitava se tako standard koji bi, jasno, trebale u svoja zakonodavstva i praksu uvrstiti zemlje stranke konvencije - kažnjavanje medija i novinara moguće je samo ukoliko za to postoje 'osobito jaki razlozi'.

Utjecajna analiza prakse Europskog suda u odnosu na slobodu izražavanja, izdvaja temeljne demokratske standarde koji su se iskristalizirali u odnosu na slobodu medija (tiska). ${ }^{4}$ Ono što je Sudu bitno za procjenu u svakom konkretnom slučaju jest odgovor na pitanje jesu li novinari djelovali u dobroj vjeri u cilju opskrbljivanja javnosti točnim i pouzdanim informacijama u skladu s novinarskom etikom. ${ }^{5}$ Europski je sud s više presuda ustanovio standard po kojem javne osobe uživaju nižu razinu zaštite prava na privatnost od ostalih, što znači i da ostali u odnosu na njih imaju manje ograničenja pa samim time i veći opseg slobode izražavanja. ${ }^{6}$ Javne se ličnosti u ovom pogledu također razlikuju. Naime, ograničenja slobode izražavanja manja su u odnosu na političare nego na ostale javne osobe. A sloboda izražavanja u pogledu državnih tijela vlasti, naročito Vlade, vrlo je široka.

Ustav Republike Hrvatske dosljedno propisuje ograničenja slobodi izražavanja u skladu s odredbama Europske konvencije i tumačenjima, odnosno standardima, koje je iznjedrila praksa Europskog suda. Navedeno je, jasno, u skladu i s odredbama ostalih mjerodavnih, ranije u tekstu spomenutih, međunarodnih ugovora. Iz konvencijskih ${ }^{7}$ pa tako i ustavnih odredbi proizlazi da su dvije vrste ograničenja slobode izražavanja: ona koja za svrhu imaju zaštitu prava drugih (prava na zaštitu

3 Alaburić, M., op. cit. u bilj 1, str. 47.

4 Alaburić, M., op. cit. u bilj 1, str. 22-26.

5 Presude Europskog suda iz kojih se iščitava ovaj demokratski standard: Jersild v. Denmark, od 23. rujna 1994., Series A No. 298., Oberschlick v. Austria (No.1.), od 23. svibnja 1991., Series A No. 204., Bladet Tromso and Stensaas v. Norway, od 20. svibnja 1999., Fressoz and Roire, od 21. siječnja 1999. (2000.).

6 Npr. presude: Krone Verlag Gmbh\&co. KG v Austria (2002.), Lopez Gomez da Silva v.Portugal

7 Čl. 10. st. 2. Europske konvencije za zaštitu ljudskih prava i temeljnih sloboda i protokol pročišćeni tekst, Narodne novine, Međunarodni ugovori, br18/97, 6/99, 14/02, 13/03, 9/05, 1/06, 2/10, te čl. 12. Međunarodnog pakta o građanskim i političkim pravima, Narodne novine, Međunarodni ugovori $12 / 93$. 
osobnog i obiteljskog života, dostojanstva, ugleda i časti) te ona koja za svrhu imaju zaštitu nacionalne sigurnosti, javnog poretka, javnog zdravlja i morala. Tako Ustav u članku 35. jamči svakome poštovanje i pravnu zaštitu osobnog i obiteljskog života, dostojanstva, ugleda i časti. U svrhu zaštite prava na privatnost Ustav naročito jamči slobodu i tajnost dopisivanja i svih drugih oblika općenja (čl. 36.), te sigurnost i tajnost osobnih podataka (čl. 37.). Ustav slobodu izražavanja ograničava zabranom govora mržnje koji može ugroziti ne samo prava drugih, već i nacionalnu sigurnost i javni poredak (čl. 39. Ustava).

U vrlo su uskoj vezi sloboda izražavanja i sloboda savjesti i vjeroispovijesti koje Ustav jamči u čl. 40., sukladno svim relevantnim međunarodnopravnim dokumentima. S jedne strane, ove se dvije slobode međusobno podržavaju, ali u određenim se slučajevima mogu naći suprotstavljene pa treba procijeniti koja od njih u konkretnom slučaju treba imati prevagu.

Konvencijama i Ustavom RH zajamčena izražavanja misli, posljedično i njezina ograničenja, razrađuje se u sljedećim organskim zakonima:

Zakon o medijima, ${ }^{8}$

Zakon o zaštiti osobnih podataka, ${ }^{9}$

Zakon o pravu na pristup informacijama, ${ }^{10}$

Zakon o Hrvatskoj radioteleviziji, ${ }^{11}$

Ograničenja slobode izražavanja u Zakonu o medijima.

Stupanjem na snagu Zakona o medijima, koji je donio Hrvatski sabor na sjednici 30. travnja 2004. godine, prestao je važiti Zakon o javnom priopćavanju. ${ }^{12}$

U pogledu regulative i zaštite slobode izražavanja učinjen je veliki pomak u smislu normativnog usklađivanja s međunarodnim standardima. Novim je zakonom propisano da će se isti primjenjivati i tumačiti sukladno Europskoj konvenciji za zaštitu ljudskih prava i temeljnih sloboda. ${ }^{13}$ Sa Zakonom o javnom priopćavanju to nije bio slučaj.

8 Zakon o medijima, Narodne novine br. 59/04., 84/11. i 84/13.

9 Zakon o zaštiti osobnih podataka, Narodne novine br. 103/03., 118/06., 41/08., 130/11. i 106/02.

10 Zakon o pravu na pristup informacijama, Narodne novine br. 25/13. - pročišćeni tekst i 85/15.

11 Narodne novine br. 25/03., 137/10. i 76/12.

12 Zakon o Hrvatskoj radioteleviziji, Narodne novine br. 83/96., 105/97., 143/98., 20/00. i 96/01. Sukladno važećim propisima Republike Hrvatske zakon stupa na snagu osmog dana od dana objave u Narodnim novinama.

13 Zakon o medijima, čl. 1. st. 2. 


\section{OGRANIČENJA SLOBODE IZRAŽAVANJA U ZAKONU O MEDIJIMA}

Zakon o medijima jamči slobodu izražavanja i slobodu medija. ${ }^{14}$ Sloboda medija znatno je širi pojam, a sloboda izražavanja tek je jedan njezin element. ${ }^{15}$ Zakon u čl. 3. st. 3. propisuje razloge zbog kojih je dopušteno ograničiti medijske slobode. Sukladno navedenoj zakonskoj odredbi ograničenja su dopuštena "samo kada je i koliko je to nužno u demokratskom društvu radi interesa nacionalne sigurnosti, teritorijalne cjelovitosti ili javnoga reda i mira, sprječavanja nereda ili kažnjivih djela, zaštite zdravlja i morala, zaštite ugleda ili prava drugih, sprječavanja odavanja povjerljivih informacija ili radi očuvanja autoriteta i nepristranosti sudbene vlasti samo na način propisan zakonom."16

Navedeno se ograničenje, jasno, odnosi i na slobodu izražavanja kao jednu od medijskih sloboda, a u potpunosti je sadržajno, velikim dijelom čak i terminološki, usuglašeno s čl. 10. st. 2. Europske konvencije za zaštitu ljudskih prava i temeljnih sloboda. ${ }^{17}$

Iduće ograničenje slobode medija koje ponajviše 'pogađa' upravo slobodu izražavanja kao njezin derivat propisano je čl. 3. st. 4. Zakona o medijima koji kaže: "Zabranjeno je prenošenjem programskih sadržaja u medijima poticati ili veličati nacionalnu, rasnu, vjersku, spolnu ili drugu neravnopravnost ili neravnopravnost na temelju spolne orijentacije, kao i ideološke i državne tvorevine nastale na takvim osnovama, te izazivati nacionalno, rasno, vjersko, spolno ili drugo neprijateljstvo ili nesnošljivost, neprijateljstvo ili nesnošljivost na temelju spolne orijentacije, poticati nasilje i rat."

Iz navedenog je članka očito kako načelo zabrane diskriminacije predstavlja jedno od temeljnih ograničenja slobode izražavanja. Ovdje je zapravo riječ o dvostrukoj zabrani: zabrani diskriminacije i govora mržnje. Da je ovakvo ograničenje u potpunosti u skladu s međunarodnim demokratskim standardima, svjedoče ponajbolje tumačenja Europskog suda za ljudska prava prema kojima govor mržnje ne uživa zaštitu čl. 10. Konvencije, a potrebno ga je razlikovati od govora koji je šokantan, neugodan, možebitno i uvredljiv, ali koji uživa konvencijsku

14 Ibid., čl. 3.2. t. 1.

15 Uz slobodu izražavanja mišljenja sloboda medija, sukladno čl. 3. st. 2. Zakona o medijima, obuhvaća: neovisnost medija, slobodu prikupljanja, istraživanja, objavljivanja i raspačavanja informacija u cilju informiranja javnosti; pluralizam i raznovrsnost medija, slobodu protoka informacija i otvorenost medija za različita mišljenja, uvjerenja i za raznolike sadržaje, dostupnost javnim informacijama, uvažavanje zaštite ljudske osobnosti, privatnosti i dostojanstva, slobodu osnivanja pravnih osoba za obavljanje djelatnosti javnoga informiranja, tiskanja i raspačavanja tiska i drugih medija iz zemlje i inozemstva, proizvodnju i objavljivanje radijskog i televizijskog programa, kao i drugih elektroničkih medija, autonomnost urednika, novinara i ostalih autora programskih sadržaja u skladu s pravilima struke.

16 Zakon o medijima, čl. 3. st. 3.

17 Ograničenja sloboda koje obuhvaća sloboda izražavanja prema ovoj odredbi Europske konvencije mogu podlijegati ograničenjima "predviđenim zakonom i koja su neophodna u demokratskom društvu u interesu nacionalne sigurnosti, teritorijalnog integriteta ili javne sigurnosti, sprječavanja nereda ili zločina, zaštite zdravlja i morala, ugleda ili prava drugih, sprječavanja širenja povjerljivih informacija ili u interesu očuvanja integriteta i nepristranosti sudstva". 
zaštitu. Europski je sud tako zauzeo stav da je u demokratskim društvima "nužno sankcionirati, čak i sprječavati sve oblike izražavanja kojima se širi, raspiruje, potiče i pravda mržnja zasnovana na netoleranciji". ${ }^{18}$

Iduće bitno ograničenje koje, sukladno čl. 12. Univerzalne deklaracije o ljudskim pravima, čl. 10. st. 2. Europske konvencije za zaštitu ljudskih prava i temeljnih sloboda te čl. 19. st. 3. Međunarodnog pakta o građanskim i političkim pravima, kao i čl. 35. Ustava Republike Hrvatske, propisuje i Zakon o medijima - pravo je na zaštitu privatnosti, dostojanstva, ugleda i časti. Kao što je razvidno iz članka 7. Zakona o medijima, ne uživaju svi građani ovo pravo u jednakom obujmu. Naime, sukladno čl. 7. st. 2., osobe koje obavljaju javnu službu ili dužnost nemaju pravo na zaštitu privatnosti u slučajevima koji su u svezi s tom javnom službom ili dužnosti. Iz čl. 7. st. 3. proizlazi kako osobe koje svojim izjavama, ponašanjem i drugim djelima u vezi sa svojim osobnim ili obiteljskim životom same privlače pažnju javnosti ne mogu zahtijevati istu razinu zaštite privatnosti kao drugi građani.

Navedene zakonske odredbe u potpunosti su u skladu s međunarodnim demokratskim standardom koji se iskristalizirao kroz praksu Europskog suda za ljudska prava, a prema kojemu javne ličnosti, a naročito političari, ne uživaju jednaku zaštitu prava na privatnost. ${ }^{19}$

Temeljem članka 8. Zakona o medijima nema povrede prava na zaštitu privatnosti ako u pogledu informacije prevladava opravdani javni interes nad zaštitom privatnosti u odnosu na djelatnost novinara ili na informaciju. Procjenu koji interes prevladava u danom slučaju domaći bi sudovi trebali raditi po uzoru na praksu Europskog suda za ljudska prava, prema već izloženom kriteriju. Europski je sud nacionalnim sudovima država članica za procjenu dao i vrlo konkretne smjernice koje je utvrdio kroz praksu. Tako se stvarima od javnog interesa ne smatraju: financijsko stanje poznatih ličnosti, osim u posebnim slučajevima kada je riječ o političarima, gospodarstvenicima i slično; fotografije ili informacije iz privatnog života javne ličnosti koje imaju za jedinu svrhu zadovoljiti radoznalost javnosti, kao što je bio slučaj s Carolinom von Hannover, nisu od javnog interesa, kao ni glasine o bračnim problemima političara.

Daljnja ograničenja slobode izražavanja putem medija proizlaze iz članka 16. Zakona o medijima. "Mediji su dužni poštovati privatnost, dostojanstvo, ugled i čast građana, a osobito djece, mladeži i obitelji bez obzira na spol i spolno opredjeljenje. Zabranjuje se objavljivanje informacija kojima se otkriva identitet djeteta, ukoliko se time ugrožava dobrobit djeteta.

18 Mole, N., Reynolds, J., Mijović, Lj., Sloboda izražavanja i pravo na privatnost prema Europskoj konvenciji o ljudskim pravima, Priručnik o sudskoj praksi Europskog suda za ljudska prava, AIRE centar, Prijevod Alpha Team, 2011., str. 15.

19 Iako se ovo, jednako kao i veća razina slobode izražavanja koju imaju novinari, naizgled može činiti kao diskriminatorna praksa, ona ima svoju osnovu u javnom interesu. Ili, kako je konstatirao Hayek: "Ako želite izjednačiti ljude koji su u svakom pogledu nejednaki, morate s njima različito postupati." (Hayek, F. A., Politički ideal vladavine prava, Preveo Arsen Bačić, Školska knjiga Zagreb, 1994., str. 62.). Novinari su "psi čuvari demokracije", a političari oni koji je, ako ne vode računa o javnom interesu, mogu potkopati. U tom smislu velika je razlika kako između njih, tako i "običnih" građana, te je nejednako postupanje u pogledu slobode izražavanja itekako opravdano. 
Dr. sc. Ivana Mijić Vulinović: Ograničenja slobode izražavanja u Republici Hrvatskoj u odnosu na... Zbornik radova Pravnog fakulteta u Splitu, god. 58, 3/2021, str. 967-988

Mediji su dužni poštovati pravo na zaštitu identiteta svjedoka i oštećenika kaznenih djela, i bez njihova znanja i pristanka ne smiju otkriti njihov identitet."

Posebna zaštita djece, mladeži i obitelji, kao i identiteta svjedoka i oštećenika kaznenih djela međunarodni je demokratski standard koji proizlazi iz brojnih konvencija, od kojih je svakako najznačajnija Konvencija o pravima djeteta.

\section{ZAŠTITA PRIVATNOSTI KAO OGRANIČENJE SLOBODE IZRAŽAVANJA}

Jedno od glavnih prava koje se stavlja na vagu sa slobodom izražavanja jest pravo na privatnost. Tako se i prema praksi Europskog suda za ljudska prava najčešce u istim predmetima razmatraju čl. 10. i čl. 8. Konvencije koji glasi: "1. Svatko ima pravo na poštovanje svog privatnog i obiteljskog života, doma i prepiske. Javne vlasti neće se miješati u izvršenje ovog prava osim ako je takvo miješanje predviđeno zakonom i ako je to neophodna mjera u demokratskom društvu u interesu nacionalne sigurnosti, javne sigurnosti, ekonomske dobrobiti zemlje, radi sprečavanja nereda ili kriminala, zaštite zdravlja i morala ili zaštite prava i sloboda drugih."

Zakon koji ga ponajviše štiti u Republici Hrvatskoj jest Zakon o zaštiti osobnih podataka. Sukladno čl. 1., isti regulira zaštitu osobnih podataka o fizičkim osobama kao i nadzor nad njihovim prikupljanjem, obradom i korištenjem. Bez ikakve diskriminacije, zaštita osobnih podataka sukladno ovom Zakonu zajamčena je svakoj fizičkoj osobi bez obzira na državljanstvo i prebivalište.

Već iz čl. 1.a. Zakona jasno je da je isti u skladu s međunarodnim demokratskim standardima, s obzirom na to da, kako se navodi, sadrži odredbe koje su u skladu s aktima Europske unije i to: Direktivom 95/46/EZ Europskog parlamenta i Vijeća od 24. listopada 1995. godine, o zaštiti pojedinaca u vezi s obradom osobnih podataka i slobodnom prijenosu takvih podataka (CELEX 31995L0046). ${ }^{20}$

Izražavanje koje uključuje iznošenje tuđih osobnih podataka, a da za to ne postoji poseban na zakonu utemeljen razlog, nedopušteno je. Osobne podatke državna tijela vlasti i druge pravne i fizičke osobe, sukladno čl. 6. Zakona, smiju prikupljati isključivo u svrhu s kojom je ispitanik upoznat, koja je izričito navedena i u skladu sa zakonom. Ti se podaci dalje smiju obrađivati isključivo u svrhu u koju su prikupljeni. Sukladno čl. 7. Zakona, prikupljanje i obrada osobnih podataka dopušteni su kada je ispitanik dao privolu i isključivo u svrhu za koju je ista dana. Postoje jasno zakonom predviđeni slučajevi kada je moguće prikupljati i obrađivati osobne podatke bez privole ispitanika. Jedan je od tih slučajeva predviđen samim Zakonom o zaštiti osobnih podataka (čl. 7.) kada je obrada nužna radi ispunjenja

20 "Osobni podatak je svaka informacija koje se odnosi na identificiranu fizičku osobu ili fizičku osobu koje se može identificirati (u daljnjem tekstu, ispitanik); osoba koje se može identificirati je osoba čiji se identitet može utvrditi izravno ili neizravno, posebno na osnovi identifikacijskog broja ili jednog ili više obilježja specifičnih za njezin fizički, psihološki, mentalni, gospodarski, socijalni ili kulturni identitet" (Zakon o zaštiti osobnih podataka, čl. 2. st. 1.). 
zadataka u javnom interesu. Za prikupljanje i obradu osobnih podataka maloljetnika predviđene su posebne mjere zaštite. ${ }^{21} \mathrm{U}$ Republici Hrvatskoj, sukladno međunarodnim standardima, vode se zbirke osobnih podataka. Sukladno čl. 11. Zakona o zaštiti osobnih podataka, voditelj pojedine zbirke ovlašten je osobne podatke dati na korištenje drugim primateljima samo na temelju njihova pisanog zahtjeva ako je to potrebno radi obavljanja poslova u okviru zakonom utvrđene djelatnosti primatelja. ${ }^{22}$ Pisani zahtjev, nalaže Zakon, mora sadržavati svrhu i pravni temelj za korištenje osobnih podataka kao i vrstu zatraženih podataka.

Kako bi se uspostavila što učinkovitija kontrola nad upotrebom osobnih podataka, čl. 11. Zakona propisuje obvezu voditelja zbirke da vodi posebnu evidenciju o osobnim podacima koji su dani na korištenje, primateljima i svrsi za koju su dani. Iz istog članka razvidno je ograničenje slobode izražavanja znanstvenika-istraživača. Njima je, naime, zabranjeno koristiti osobne podatke omogućavanjem identifikacije osobe na koju se podaci odnose.

Sukladno čl. 19. Zakona o zaštiti osobnih podataka, ispitanici imaju pravo podnijeti zahtjev da im se dostavi ispis podataka o tome tko je i za koje svrhe i po kojem pravnom temelju dobio na korištenje osobne podatke koji se odnose na njega. Voditelji zbirke osobnih podataka imaju obvezu dostaviti potvrdu o navedenome najkasnije trideset dana od podnošenja zahtjeva.

Poštovanje zakonskih odredbi dodatno se osigurava kaznenim odredbama kojima su propisane novčane kazne za državne organe vlasti zadužene za prikupljanje i obradu osobnih podataka ako to rade suprotno odredbama Zakona o zaštiti osobnih podataka. ${ }^{23}$

\section{KAZNENOPRAVNA OGRANIČENJA SLOBODE IZRAŽA VANJA}

Sukladno čl. 10. st. 2. Europske konvencije za zaštitu ljudskih prava i temeljnih sloboda, izražavanje propisanim zakonom može biti podvrgnuto kaznama koje su u demokratskom društvu nužne radi zaštite ugleda ili prava drugih. Kazneno zakonodavstvo Republike Hrvatske isprva nije bilo usklađeno s međunarodnim demokratskim standardima, ali se reformama od 90-ih godina prošlog stoljeća do danas u potpunosti s njima uskladilo (1997., 2006., 2011. i 2015. godine). Krivični zakon Republike Hrvatske iz 1992. u potpunosti je preuzeo kaznenopravnu regulativu kaznenih djela protiv časti i ugleda iz Krivičnog zakona Socijalističke

21 Obiteljskim zakonom, Narodne novine, br.116/2003, 17/2004, 136/2004, 107/2007, Kaznenim zakonom, Narodne novine, br.125/11, 144/12, 56/15, 61/15, 101/17, 188/18, Zakonom o kaznenom postupku, Narodne novine, br.152/08, 121/11, 70/17.

${ }_{22}$ Zakon o zaštiti osobnih podataka u čl. 2. st. 6. primatelja određuje kao fizičku ili pravnu osobu, državno ili drugo tijelo kojem se osobni podaci otkrivaju, neovisno o tome je li on ujedno i treća strana ili nije.

23 Ibid, čl. 36. 
Dr. sc. Ivana Mijić Vulinović: Ograničenja slobode izražavanja u Republici Hrvatskoj u odnosu na... Zbornik radova Pravnog fakulteta u Splitu, god. 58, 3/2021, str. 967-988

Republike Hrvatske iz 1977. godine. ${ }^{24}$ Analizirajući dvije velike reforme kaznenog zakonodavstva Republike Hrvatske, Grozdanić i Škorić opisuju dva posve suprotna trenda.

Reformom 1997. (Kazneni zakon, Narodne novine, 110/1997.) od bivše države preuzeto zakonodavstvo ublažilo je kaznenopravnu represiju. Izmjene su išle u smjeru davanja prevage novčanoj kazni nad zatvorskom te što većoj individualizaciji kazne. ${ }^{25}$

Regulativa kaznenih djela protiv časti i ugleda, proizlazi iz navedenoga, slijedila je opći trend u kaznenom zakonodavstvu te posebni trend u pogledu slobode izražavanja.

Usprkos pomacima u smjeru proširenja slobode izražavanja, Kazneni zakon iz 1997. nije u potpunosti bio u skladu s međunarodnim demokratskim standardima. Ograničenje slobode izražavanja ponajviše se ogledalo u preširokom određenju kaznenog djela klevete koja je, kako ističe Novoselec, bila najveća slabost tog uređenja. Klevetu je, sukladno čl. 200. st. 1. Kaznenog zakona iz 1997. činio onaj "tko iznese ili pronese nešto neistinito što može škoditi časti ili ugledu drugoga". Novoselec upućuje na st. 3. istoga članka kojim se oslobađa od kažnjavanja osoba koja dokaže "opravdani razlog zbog kojeg je povjerovala u istinitost sadržaja koji je iznijela ili pronijela"... "Iz te je odredbe proizlazilo (argumentum a contrario) da je klevetu počinio i počinitelj koji je povjerovao u istinitost tvrdnje, ali za to nije imao opravdani razlog, pa je postupao iz nehaja." 26

Dakle, kako upućuje Novoselec, prema Kaznenom zakonu iz 1997., postojale su dvije vrste klevete: tipična i netipična. Za njih je bila propisana ista kazna što je, prema Novoselcu, apsurd jer "prvi oblik upućuje na veću težinu djela i veći stupanj krivnje, dok je drugi lakši... Nije svejedno iznosi li počinitelj objektivno neistinite tvrdnje znajući da su neistinite ili tvrdnje za koje ne zna jesu li istinite (što je upravo karakteristično za novinarsku djelatnost."27

Nadalje, kako upozorava Novoselec, najveće je poteškoće preširoko određenje klevete predstavljalo pri određivanju opsega isključivanja protupravnosti za kaznena

24 Kaznena djela protiv časti i ugleda opća su kaznena djela (delictum communium), što znači da počinitelj može biti svaka osoba. Riječ je o komisivnim deliktima (koji se izvršavaju činjenjem). I u pravilu nema kažnjavanja za pokušaj. Više u: Bardov, S., "Kaznena djela protiv časti i ugleda u hrvatskom kaznenom pravu", Pravnik; časopis za pravna i društvena pitanja, Vol. 41, br. 84, 2007., str. 61-94, str. 63.

25 Grozdanić, V., Škorić M., "Izmjene Kaznenog zakona - od znatnog ublažavanja do znatnog pooštrenja kaznenopravne represije", Zbornik Pravnog fakulteta Sveučilišta Rijeka, Vol. 27, br. 2., 2006. , str. 821-848, str. 822., 2006.: "Pored toga, tendencija izricanja sve blažih kazni po vrsti i mjeri i osobito njihovo zamjenjivanje nepunitivnim sankcijama bila je uočljiva u sudskoj praksi europskih država pa se može reći da je redukcija kaznenopravne prisile bila europski trend kontinuirane tendencije ublažavanja kaznenopravne represije i kaznenopravnih sankcija."

"Nema nikakve sumnje da je novo hrvatsko kazneno zakonodavstvo iz 1997., ublažavanjem represije na normativnom nivou, nastojalo kazne usuglasiti sa suvremenim kaznenim zakonima, ali i s kaznenom politikom naših sudova."

26 Novoselec, P., "Zaštita časti i ugleda u novom Kaznenom zakonu", Zbornik Pravnog fakulteta u Zagrebu, Vol. 66, br. 4, str. 443-468, str. 445.

27 Ibid, str. 446., et passim. 
djela protiv časti i ugleda. Naime, članak 203. Kaznenog zakona iz 1997. godine izrijekom je dopustio isključenje protupravnosti za klevetu i to za oba njena oblika, za nehajno i svjesno klevetanje.

Dakle, "široko postavljeno isključenje protupravnosti značilo je i da počinitelj klevete ima pravo na klevetu, uključujući i klevetu koja se sastojala u svjesnom iznošenju difamantnih tvrdnji". ${ }^{28}$

Problem izrazito laganog isključenja protupravnosti za klevetu koji se protezao iz ranijih zakonodavnih rješenja Kazneni zakon iz 1997. pokušao je riješiti odredbom čl. 203 koji propisuje da isto nije moguće ako je djelo "imalo za cilj naškoditi nečijoj časti i ugledu".

Reforma koja se provodila od 2004. do 2006. godine išla je u drugom smjeru - pooštrenja kaznenopravne represije. ${ }^{29}$ Opisujući navedeno, Grozdanić i Škorić upućuju na specifičnost kaznenopravne regulative u pogledu kaznenih djela protiv časti i ugleda. Naime, tijekom druge reforme kod ovih je kaznenih djela, suprotno općem trendu, došlo do ublažavanja represije - kazna zatvora za njih je u potpunosti isključena te je od 2006. jedina moguća kazna za kaznena djela protiv časti i ugleda novčana. ${ }^{30}$ Navedeno ide u prilog zaštiti slobode izražavanja, a u potpunosti je u skladu s međunarodnim demokratskim standardima.

Određena rješenja ovoga zakona ipak nisu u skladu s međunarodnim standardima. $\mathrm{Na}$ jedno od njih upozorava Novoselec, a tiče se isključenja protupravnosti za klevetu koje je ovaj zakon preuzeo iz ranijih.

"Isključenje protupravnosti za klevetu ne dopuštaju ni strani zakoni. To nije moguće u švicarskom pravu, a i prema stajalištima njemačke doktrine odredba 193. Njemačkog kaznenog zakonika o isključenju protupravnosti ne može se primijeniti na klevetu." 31

U pokušaju da suzi opseg isključenja protupravnosti za klevetu čl. 203. Kaznenog zakona novelom 2004. godine izmijenjen je na način da je osuda moguća "ako iz načina izražavanja i drugih okolnosti jasno proizlazi da se radi o ponašanju koje je imalo za cilj samo naškoditi nečijoj časti i ugledu."

"Osobito je novela iz 2004. otvorila put samovolji sudaca jer se uvijek mogao naći, osim cilja škoditi nečijoj časti i ugledu, i neki drugi cilj (npr. kod novinara da idu za informiranjem javnosti ili čak za povećanom prodajom novina) te zaključiti da počinitelj nije imao za cilj samo škoditi nečijoj časti i ugledu i biti oslobođen. Zato i ne čudi da je sudska praksa bila neujednačena." ${ }^{32}$

Neujednačena sudska praksa svakako je u potpunoj suprotnosti s međunarodnim demokratskim standardima. Razvidno iz sudskih presuda i iz izvješća relevantnih tijela, Republika Hrvatska institucionalno nije bila u skladu s međunarodnim

28 Ibid, str. 447.

29 Vidi: Zakon o izmjenama i dopunama Kaznenog zakona, Narodne novine, 71/2006.

30 Vidi: Grozdanić, V., Škorić, M., op. cit., str. 824.

31 Novoselec, P., op. cit., str. 447.

32 Ibid, str. 449. 
standardima. Sukladno napucima Parlamentarne skupštine Vijeća Europe i prakse Europskog suda za ljudska prava, propisi kojima se kažnjava kleveta trebaju se primijeniti suzdržano, a i oni sami trebaju biti vrlo precizni, kleveta treba biti usko određena. U suprotnom, postoji opasnost od ozbiljnog narušavanja slobode izražavanja. ${ }^{33}$

Najznačajnija reforma kaznenog zakonodavstva u pogledu regulative kaznenih djela protiv časti i ugleda provedena je u okviru donošenja novog Kaznenog zakona 2011. godine.

Osim što je kazneno djelo klevete znatno suženo, uvedeno je novo kazneno djelo, sramoćenje, a ukinuto iznošenje osobnih ili obiteljskih prilika i predbacivanje kaznenog djela. Osim toga ukinuta je i odredba u kojoj se propisuju razlozi za isključenje protupravnosti kaznenih djela protiv časti i ugleda. ${ }^{34}$

Kazneno djelo sramoćenja novelom iz 2015. godine, po uzoru na švicarski Kazneni zakonik, preimenovano je u teško sramoćenje. ${ }^{35}$ Sukladno čl. 148. st. 1., ovo čini onaj tko pred drugim za nekoga iznese ili pronese činjeničnu tvrdnju koja može škoditi njegovoj časti ili ugledu. Razlika je u odnosu na sramoćenje to da se za njega tražilo da ta činjenična tvrdnja bude neistinita. Dakle, teško sramoćenje u većoj mjeri ograničava slobodu izražavanja od samog sramoćenja. Zato su se iz novinarskih krugova, ali i dijela akademske zajednice, mnogi usprotivili ovoj izmjeni, ali ona je ipak provedena.

U praksi je teško razgraničiti teško sramoćenje od uvrede. Naime, predmet teškog sramoćenja činjenična je tvrdnja, a uvrede vrijednosni sudovi, koje je ponekad zaista teško razlučiti. S obzirom da su činjenične tvrdnje predmet ovih djela, još je teže u pojedinim situacijama razlikovati teško sramoćenje od klevete. Mišljenja smo da su kaznena djela uvrede i klevete sasvim dostatna za zaštitu ljudskih prava koja mogu biti ugrožena prekoračenjem slobode izražavanja. Kazneno djelo teško sramoćenje stvara poteškoće u sudskoj praksi, a i predstavlja nepotrebnu dodatnu kriminalizaciju nečega što je već kriminalizirano (uvredom u klevetu). Prema tome, držimo da bi to kazneno djelo korisno bilo ukinuti.

Dakle, pod kazneno zakonodavstvo Republike Hrvatske koje se odnosi na slobodu izražavanja spada više odredbi Kaznenog zakona od kojih pojedine jamče, a ostale ograničavaju ovo ljudsko pravo. Čl. 127. propisuje kaznu zatvora i to do jednu godinu za onoga tko uskrati ili ograniči slobodu govora ili javnog nastupa, slobodu tiska ili drugih sredstava priopćavanja ili slobodno osnivanje ustanova javnog priopćavanja. Navedenom će se kaznom, sukladno stavku 2. ovoga članka, kazniti onaj tko naredi ili provodi cenzuru, ili novinaru protupravno uskrati ili ograniči slobodu izvještavanja. Kao i, sukladno st. 3. ovoga članka, onaj tko protupravno spriječi tiskanje, prodaju ili raspačavanje knjiga, časopisa, novina ili drugih tiskanih stvari ili proizvodnju i emitiranje radijskog i televizijskog programa, programa novinskih agencija ili objavljivanje drugih medijskih sadržaja.

33 Vidi: Mole, N., Reynolds J., Mijović, Lj., op. cit., str. 26.

34 Kazneni zakon, Narodne novine br. 110/97., čl. 203.

35 Vidi: Kazneni zakon, Narodne novine br. 61/2015., čl. 173. 
Ograničenje slobode izražavanja zbog zaštite prava na čast i ugled regulira se Glavom 15. Kaznenog zakona koja nosi naziv: Kaznena djela protiv časti i ugleda. Njih je danas, dakle, tri: uvreda, teško sramoćenje i kleveta. Za sve je propisana isključivo novčana kazna. I ne kažnjava se pokušaj.

Sukladno međunarodnim demokratskim standardima, ne kažnjava se svaki napad na ugled. Prema Europskom sudu za ljudska prava, bitno je da je napad na ugled "... dostigao određeni nivo ozbiljnosti i ako je izveden na način koji prouzrokuje štetu ličnom uživanju prava na poštovanje privatnog života." 3637

Odredbe kaznenog zakona Republike Hrvatske u skladu su s navedenim međunarodnim demokratskim standardom što se iščitava iz odredbi o oslobađanju od kazni, nepostojanju kaznenog djela i razlozima za isključenje protupravnosti. Tako sud može osloboditi počinitelja kaznenog djela uvrede kazne u dva slučaja. Prvi (st. 3. čl. 147.), ako uvrijeđeni uzvrati uvredu pa se oba počinitelja tada oslobađa. I drugi (st. 4. čl. 147.), "ako je počinitelj bio izazvan nedoličnim ponašanjem oštećenika, ili je oštećenik pred sudom prihvatio njegovu ispriku zbog počinjenog djela". Zakonodavac je procijenio da se u ovim slučajevima ne prouzrokuje šteta uživanju prava na poštovanje privatnog života.

Teško sramoćenje, sukladno čl. 148., počinio je onaj "tko pred drugim za nekoga iznese ili pronese činjeničnu tvrdnju koja može škoditi njegovoj časti ili ugledu". ${ }^{38}$ Sukladno st. 3. čl. 148., nema kaznenog djela "ako počinitelj dokaže istinitost činjenične tvrdnje koju je iznosio ili pronosio ili postojanje ozbiljnog razloga zbog kojeg je povjerovao u njezinu istinitost". Navedena odredba u skladu je s međunarodnim demokratskim standardom koji se iskristalizirao kroz praksu Europskog suda za ljudska prava koji nalaže da svaka osoba dobije priliku dokazati istinitost činjeničnih tvrdnji o kojima se radi. ${ }^{39}$

Sukladno st. 4., nije dopušteno dokazivanje navedenih okolnosti ako se te činjenične tvrdnje odnose na osobne ili obiteljske prilike. ${ }^{40}$

Sukladno st. 5., sud može osloboditi kazne počinitelja koji prizna neistinitost svojih tvrdnji i opozove ih. Očigledno da u slučaju priznanja i opozivanja najvjerojatnije prestaje ugroza privatnog života pa stoga zakonodavac ostavlja sudu mogućnost počinitelja osloboditi kazne.

U čl. 148. a. propisani su razlozi za isključenje protupravnosti za kaznena djela uvrede i teškog sramoćenja. Tako nema kaznenog djela uvrede i teškog sramoćenja

36 Vidi: Mole, N., Reynolds, J., Mijović, Lj., op. cit., str. 25.

37 Ugled je zaštićen članom 8. Europske konvencije koji regulira pravo na poštovanje privatnog života a pod koje, od presude Pseifer protiv Austrije, i pripada. Naime, tom je presudom Sud ustanovio da ugled predstavlja dio osobnog identiteta i psihičkog integriteta svake osobe i da stoga potpada pod privatni život i uživa zaštitu u okviru članka 8. Konvencije.

38 Dakle, ne traži se više da tvrdnja bude neistinita, kao u slučaju ranijeg zakona.

39 Vidi: Mole, N., Reynolds J., Mijović, Lj., op. cit., str. 25.

Mogućnost dokazivanja istinitosti činjeničnih tvrdnji postoji u kleveti i teškom sramoćenju, dok je u uvredi riječ o nedokazivim vrijednosnim sudovima.

40 Prema svim međunarodnopravnim standardima, osobni i obiteljski život uživaju posebnu zaštitu, što se odražava navedenom odredbom. 
ako su obilježja tih kaznenih djela ostvarena u znanstvenom, stručnom, književnom, umjetničkom djelu ili u obavljanju dužnosti propisane zakonom, političke ili druge javne ili društvene djelatnosti, u novinarskom poslu ili obrani nekog prava, a to je učinio u javnom interesu ili zbog drugih opravdanih razloga. Ovaj članak iznimno je bitno jamstvo slobode izražavanja, naročito znanstvenih, umjetničkih i medijskih sloboda bez kojih ne može biti govora o slobodnom, demokratskom društvu. Ovakvo je rješenje u potpunosti u skladu s međunarodnim demokratskim standardima. Naime, član 10. Europske konvencije za zaštitu ljudskih prava i temeljnih sloboda, prema tumačenju Europskog suda, ne odnosi se samo na slobodu izražavanja istinitih činjeničnih mišljenja. Zaštićeno je i izražavanje mišljenja u vidu kritika i vrijednosnih sudova, uključujući i one koji nailaze na neodobravanje, pa čak i onih koji vrijeđaju, uznemiravaju i šokiraju. ${ }^{41}$

Važno je učiniti odmak između uvredljivog govora i govora mržnje. Govor koji je usmjeren protiv temeljnih konvencijskih vrijednosti potpada pod govor mržnje i ne uživa zaštitu članka 10. Konvencije. Komitet Vijeća ministara opisao je govor mržnje na sljedeći način: "To su svi oblici izražavanja koji šire, raspiruju, potiču ili pravdaju rasnu mržnju, ksenofobiju, antisemitizam i druge oblike mržnje zasnovane na netoleranciji." 42

I Međunarodni pakt o gospodarskim, socijalnim i kulturnim pravima u već navedenom članku 20. zabranjuje govor mržnje. Republika Hrvatska u potpunosti se normativno uskladila s ovim međunarodnim demokratskim standardom, što je razvidno iz odredbe 39. u kojoj se navodi da je "zabranjeno i kažnjivo svako pozivanje ili poticanje na rat ili uporabu nasilja, na nacionalnu, rasnu ili vjersku mržnju ili bilo koji oblik nesnošljivosti". Članak 3. st. 4. Zakona o medijima kaže: "Zabranjeno je prenošenjem programskih sadržaja u medijima poticati ili veličati nacionalnu, rasnu, vjersku, spolnu ili drugi neravnopravnost ili neravnopravnost na temelju spolne orijentacije, kao i ideološke i državne tvorevine nastale na takvim osnovama, te izazivati nacionalno, rasno, vjersko, spolno ili drugo neprijateljstvo ili nesnošljivost, neprijateljstvo ili nesnošljivost na temelju spolne orijentacije, poticati nasilje i rat." Mada se ovdje izrijekom ne spominje govor mržnje, jasno je da poticanje ili veličanje neravnopravnosti te izazivanje neprijateljstva ili nesnošljivosti, predmnijevaju mržnju prema drugačijima te predstavljaju izraz te mržnje u nacionalnom, vjerskom, rasnom ili spolnom pogledu. Tako se i ovaj članak može smatrati usklađivanjem s međunarodnim demokratskim standardom koji priječi govor mržnje.

41 Vidi: Mole, N., Reynolds, J., Mijović, Lj., op. cit., str. 12.

42 Vidi: Preporuka Odbora ministara Vijeća Europe, No. R. (97) 20, 30. listopada 1997., https:// rm.coe.int.

Više o govoru mržnje i kriterijima Suda pri ocjeni potpada li neko izražavanje pod govor mržnje ili ne vidi: Mole, N., Reynolds, J., Mijović, Lj., op. cit., str. 15. 
I u Zakonu o elektroničkim medijima, i to izrijekom, zabranjuje se govor mržnje. Članak 12. st. 2. tako zabranjuje pogodovanje, poticanje i širenje mržnje ili diskriminacije po svim osnovama diskriminacije. ${ }^{43}$

Klevetu, sukladno čl. 149., čini onaj "tko pred drugim za nekoga iznese ili pronese neistinitu činjeničnu tvrdnju koja može škoditi njegovoj časti ili ugledu, znajući da je neistinita". Neistinitost je činjenične tvrdnje, dakle, za razliku od ranijeg zakonskog rješenja, bitno obilježje kaznenog djela. Kleveta se može počiniti samo svjesno a nipošto, kao što je ranije bilo moguće, iz nehaja. Dakle, samo namjerno iznošenje ili prenošenje neistinitih činjeničnih tvrdnji zakonodavac smatra ozbiljnim napadom na ugled.

Kvalificirani oblik uvrede, teškog sramoćenja i klevete, čini onaj tko drugoga kleveće putem tiska, radija, televizije, računalnog sustava ili mreže, na javnom skupu ili na drugi način zbog čega je ono postalo pristupačno većem broju osoba (čl. 147., st. 2., čl. 148., st. 2., čl. 149. st. 2.). Za kvalificirane oblike propisane su veće novčane kazne, a osim toga, sukladno čl. 151. st. 1. i st. 2., presude se u tim slučajevima objavljuju u cijelosti ili djelomično na zahtjev oštećenika o trošku počinitelja, kad god je to moguće, u istom sredstvu javnog priopćavanja u kojem je kazneno djelo počinjeno.

U skladu je s međunarodnim standardima i odredba čl. 150. prema kojoj se kaznena djela protiv časti i ugleda progone po privatnoj tužbi.

Za sramoćenje i za sva ostala kaznena djela protiv časti i ugleda ukinuta je zatvorska kazna, što je u potpunosti u skladu s međunarodnim demokratskim standardima. Naime, Rezolucija Europskog parlamenta 1577. poziva sve države članice da bez odlaganja ukinu zatvorske kazne za kazneno djelo sramoćenja. Iz prakse Europskog suda za ljudska prava proizlazi da se kazne zatvora smatraju prestrogima s obzirom na težinu kaznenih djela protiv časti i ugleda.

43 Koliko god slobodu izražavanja treba široko tumačiti, toliko njezine izuzetke, odnosno ograničenja, prema stavu koji je praksom zauzeo Europski sud za ljudska prava, treba vrlo restriktivno tumačiti. Da je zakonodavac u Republici Hrvatskoj uvažio ovaj međunarodni demokratski standard, evidentno je iz izloženih ustavnih i zakonskih odredbi u kojima se vrlo konkretno opisuju ta ograničenja, poglavito u Kaznenom zakonu dviju grupa kaznenih djela: protiv časti i ugleda te protiv privatnosti. Kako nalažu međunarodni demokratski standardi (čl. 10 Europske konvencije za zaštitu ljudskih prava i temeljnih sloboda), ograničenja moraju biti propisana isključivo zakonima, što u Republici Hrvatskoj jesu. Jasno trebaju biti određene svrhe ograničenja, što već jest u samom Ustavu, kao i u organskim zakonima. Već iz samog naziva dviju glava Kaznenog zakona, koje propisuju kaznena djela koja ograničavaju slobodu izražavanja, jasno je kako su legitimni ciljevi miješanja u slobodu izražavanja zaštita ugleda i prava drugih te zaštita privatnog života. Na koncu, moraju biti neophodna u demokratskom društvu. Najprije zakonodavac utvrđuje koja su ograničenja neophodna u demokratskom društvu pa utvrđuje da će samo namjerno iznošenje neistinitosti o drugome biti zabranjeno, dok nehajno neće i slično. Prepušta sudu u pojedinim slučajevima omjeriti je li ograničenje razmjerno cilju kojem se teži. Tako će sud odrediti hoće li osobu osloboditi kazne za teško sramoćenje ako prizna i opovrgne ono što je iznio. 


\section{PRAKSA PRED EUROPSKIM SUDOM - PRESUDE PROTIV RH}

Europski sud za ljudska prava donio je nekoliko presuda protiv Republike Hrvatske zbog povrede slobode izražavanja.

Postupak u predmetu Jurišić protiv Hrvatske pokrenut je 2012. godine na temelju zahtjeva koji je podnijela Slava Jurišić prigovarajući da je došlo do povrede njezine slobode izražavanja zbog izricanja kaznene osude za klevetu. ${ }^{44}$ Ona je, naime, u svojstvu lokalne političarke na konferenciji za medije prozvala gradonačelnika za brojne nepravilnosti prilikom zapošljavanja u javne ustanove. Rješavajući ovaj predmet, Europski sud najprije je utvrdio kako nije sporno da osuda podnositeljice zahtjeva od nacionalnih sudova predstavlja povredu njezina prava na slobodu izražavanja. Sporno je za Sud bilo predstavlja li to miješanje povredu članka 10. Konvencije koja jamči slobodu izražavanja, a to je ukoliko ne ispunjava uvjete za ograničenje ove slobode propisane stavkom 2. ovoga članka. Za sud nije sporno da je presuda kojom je podnositeljica zahtjeva proglašena krivom za klevetu utemeljena na zakonu te da za cilj ima zaštitu prava i sloboda drugih. Ono što je Sud razmatrao jest nužnost tog miješanja u demokratskom društvu, odnosno, je li bilo razmjerno legitimnom cilju u odnosu na izrečene sankcije. I utvrdio je da nije. Nesporno je da je izjava podnositeljice na konferenciji za tisak bez sumnje narušila ugled gradonačelnika. Podnositeljica zahtjeva je, prema mišljenju Suda, kao javna ličnost imala moralnu obvezu upozoriti javnost na moguće nepravilnosti. Iz slučaja Jurišić protiv Hrvatske jasno je da Europski sud stoji pri stanovištu kako je kažnjavanje za javno izrečenu misao u političkoj debati primjereno samo u slučajevima teških kršenja temeljnih prava drugih osoba (primjerice, pozivanje na nasilje, govor mržnje i slično).

U slučaju Marunić protiv Hrvatske Sud zauzima stajalište da se osoba koja na javno upućene kritike uzvrati na isti način, temeljem slobode izražavanja ne može 'kazniti' otkazom ugovora o radu. Postupak je pokrenut temeljem zahtjeva koji je Mirela Marunić podnijela Sudu 2011. godine. ${ }^{45}$ Tvrdila je kako je došlo do povrede njezine slobode izražavanja nezakonitim otkazom zbog njezina istupa u medijima. Europski je sud utvrdio najprije kako je došlo do miješanja u podnositeljičino pravo na slobodu izražavanja zajamčenu člankom 10. st. 1. Konvencije. Nadalje, Sud je utvrdio kako je to miješanje bilo propisano zakonom, a da je težilo legitimnom cilju zaštite ugleda ili prava drugih, poslovnog ugleda i interesa tvrtke u kojoj je radila. Sud je zapravo utvrđivao je li to miješanje bilo "nužno u demokratskom društvu". Sukladno kriterijima koji su ponajbolje izraženi u predmetu Europapress Holding d.o.o. protiv Hrvatske, u ovom je slučaj sud utvrdio da miješanje u slobodu

44 Slava Jurišić protiv Hrvatske, Zahtjev br.79584/12, presuda od 8. veljače, 2018., dostupno na: https://uredzastupnika.gov.hr/UserDocsImages//dokumenti/Presude\%20i\%20odluke//Slava\%20Juri\% C5\%A1i\%C4\%87,\%20presuda.pdf

45 Marunić protiv Hrvatske, Zahtjev br. 51706/11, presuda od 28. ožujka, 2017., dostupno na: https:// uredzastupnika.gov.hr/UserDocsImages//dokumenti/Presude\%20i\%20odluke//Maruni\%C4\%87\%20 protiv\%20Hrvatske, $\% 20$ presuda.pdf 
izražavanja podnositeljice tako da joj se otkazuje ugovor o radu nije bilo "nužno u demokratskom društvu". Jer, utvrdio je Sud, "izjave podnositeljice zahtjeva u odgovoru na izjave M. U. nisu bile nerazmjerne i nisu prešle granice dozvoljene kritike". ${ }^{46}$

Sud je naglasio da je pravo na ispravak ili odgovor vrlo značajan element slobode izražavanja te da uživa zaštitu čl. 10 Konvencije. Vrlo je značajnim Sud u ovom predmetu ocijenio i činjenicu da je odgovor dan putem istog sredstva priopćavanja u kojem je podnositeljica zahtjeva prozvana i kritizirana, što govori u prilog tome da je, iznoseći kritike, ona zapravo koristila svoje pravo na obranu, odnosno odgovor. Važnim je Sud utvrdio i okolnost da je riječ o lokalnom komunalnom društvu čije je poslovanje itekako od interesa javnosti. Sud je ocijenio kako je njezino medijsko istupanje imalo dvostruku svrhu: poreći optužbe na njezin račun, ali i informiranje javnosti o stvari koja je od javnog interesa.

Kako je već istaknuto, vrlo je značajan predmet Europapress holding d.o.o. protiv Hrvatske u kojem je Sud izložio načela o zahtjevu nužnosti u demokratskom društvu.

Riječ je o najvećem izdavaču novina i časopisa u Republici Hrvatskoj. Sporni članak objavljen je u veljači 1996. u časopisu Globus pod naslovom "Ministar Š. uperio pištolj u novinarku E. V.". U istom je izvješteno o navodnom incidentu između tadašnjeg ministra financija i potpredsjednika Vlade B. Š. i novinarke tjednika Novi list E. V. Prema napisima u članku, ministar je novinarki u jednom trenutku uperio u glavu pištolj koji je uzeo od pripadnika osiguranja, rekao joj da će je ubiti pa se smijao vlastitoj šali. Bitno je napomenuti kako ovaj tekst nije prenesen kao izjava novinarke E. V. Ta je činjenica zapravo bila od ključnog značaja u sudskim postupcima koji su uslijedili.

Pred Europskim sudom stranke nisu osporavale presudu kojom se Europapress holdingu d.o.o. nalaže isplata naknade štete ministru zbog miješanja u slobodu izražavanja. Usuglašene su bile i u pogledu toga da je to miješanje bilo propisano zakonom te da je imalo legitiman cilj - zaštitu ugleda i prava drugih, konkretno, zaštitu ugleda ministra B. Ś. Ono što je bilo sporno i što je Sud razmatrao jest nužnost miješanja u demokratskom društvu. Utvrdio je da je miješanje bilo nužno te da nije došlo do povrede članka 10. Konvencije. Ovu je odluku Sud obrazložio time da podnositelj zahtjeva nije tijekom sudskih postupaka dokazao istinitost iznesenih činjeničnih navoda. A novinar koji je pisao članak ni na kakav se način nije ogradio od iznesenog činjeničnog tijeka događaja, čak nije ni naveo izvor informacije koju je prenio. S obzirom na to da je riječ o vrlo ozbiljnim optužbama, ustvrdio je Sud, bila je potrebna i ozbiljnija provjera.

Za Sud nije bilo sporno u ovom slučaju kako je javnost imala pravo znati o navodnom incidentu jer je $\mathrm{u}$ pitanju bio javni interes, a sastavni dio zadaće medija u demokratskom je društvu objaviti informacije o istome. Međutim, kako je već

46 Vidi: Europapress Holding d.o.o. protiv Hrvatske, Zahtjev br. 25333/06., Presuda od 22. listopada 2009., odlomak 54., dostupno na: https://uredzastupnika.gov.hr/UserDocsImages//arhiva// EUROPAPRESS.pdf 
napomenuto, sporan je bio način izvještavanja, a ne samo izvještavanje. U ovom je predmetu Sud naglasio da, iako nije vezan saznanjima domaćih sudova, treba vrlo uvjerljive elemente da bi od istih odstupio. Ujedno, napomenuto je kako nije protivno članku 10. Konvencije teret dokaza za klevetu prebaciti na tuženika, ali to treba biti "u skladu s razumnim standardom dokazivanja u građanskim parnicama".

U slučaju Stojanović protiv Hrvatske Europski sud je ono što su hrvatski sudovi podvukli pod klevetu okarakterizirao slobodom izražavanja. Postupak je pokrenut temeljem zahtjeva Josipa Stojanovića podnesenog u ožujku 2009. ${ }^{47}$ Podnositelj je smatrao da su domaći sudovi povrijedili njegovo pravo na slobodu izražavanja zajamčenu člankom 10. Konvencije, jer su ga osudili za klevetu zbog informacija koje je učinio dostupnim novinaru tjednika Imperijal, a koje su nanijele štetu ugledu političara, ministra zdravlja i njegova stranačkog kolege. Iako Sud nerado i vrlo rijetko odstupa od činjenica koje su utvrdili domaći sudovi, u ovom je predmetu to učinio, zaključivši da za to postoje 'uvjerljivi elementi', "imajući u vidu važnost načela da odgovornost pojedinca za klevetu ne smije prelaziti njegove ili njezine riječi, kao i mogući averzivni učinci koje kršenje tog načela može imati na slobodu izražavanja". ${ }^{48}$

Sud je u ovom predmetu također upozorio da tužitelji kod klevete ne bi smjeli ispunjavati nizak standard u pružanju dokaza, kao što je bio slučaj pred domaćim sudovima u pogledu ovog predmeta. U tom slučaju, zaključio je Europski sud, besmisleno bi bilo načelo da odgovornost za klevetu ne smije prelaziti nečije riječi.

Poricanje objavljenih klevetničkih izjava koje je izrekao ili napisao netko drugi, što su domaći sudovi isticali kao nedostatak u ovom slučaju i svojevrsnu otegotnu okolnost na strani podnositelja zahtjeva, za Europski sud je posve neopravdano. Štoviše, Sud je istaknuo da nije upoznat s takvom zakonskom odredbom ili sudskom praksom. Jedini tko je mogao poreći klevetničke izjave, usuglasio se Sud s podnositeljem zahtjeva, sam je podnositelj kao jedina osoba koja je imala zakonsko pravo na objavu opovrgavanja.

Osim toga, Sud je ovdje istaknuo još jedan standard kojega bi se i domaći sudovi trebali jasno pridržavati prilikom ocjenjivanja razmjernosti miješanja. Naime, ističe Sud, naknada štete za klevetu mora biti "u razumnom odnosu razmjera s pretrpljenim narušavanjem ugleda". Sud je presudio da je došlo do povrede čl. 10. Konvencije te je naložio isplatu nematerijalne štete podnositelju zahtjeva i naknadu troškova i izdataka.

Značajan je svakako i predmet Balentović protiv Hrvatske. Naime, Vesna Balentović Europskom je sudu u ožujku 2007. podnijela zahtjev koji je Europski sud razmotrio 2010. godine. ${ }^{49}$

47 Stojanović protiv Hrvatske, Zahtjev br. 23169/09, presuda od 19. rujna 2013., dostupno na: https:// uredzastupnika.gov.hr/UserDocsImages//arhiva//STOJANOVI\%C4\%86,\%20presuda\%20(rev).pdf

48 Presuda Hanžeković protiv Hrvatske, str. 25.

49 Balentović protiv Hrvatske, Zahtjev br.28369/07, Odluka od 30. rujna 2010., dostupno na: https:// uredzastupnika.gov.hr/UserDocsImages//arhiva//BALENOVIC,.pdf 
Sudu se obratila nakon što je iscrpila sva raspoloživa domaća pravna sredstva, smatrajući da joj je povrijeđeno pravo na slobodu izražavanja. Naime, nakon što je kao zaposlenica naftne tvrtke INA (koja je tada bila u državnom vlasništvu) u medije iznijela svoju vrlo negativnu ocjenu poslovanja tvrtke, otkazan joj je ugovor o radu. I to izvanrednim otkazom zbog toga što je "neovlaštenim istupanjem u dnevnom listu 'Slobodna Dalmacija' ... iznijela niz nestručnih analiza poslovanja i optužbi na račun... menadžmenta INE te je krajnje negativno prikazala način poslovanja INA d.d. čime je nanijela štetu ugledu INE". Osim toga, kako je bilo navedeno u obrazloženju otkaza, iznošenjem u javnost podataka o preliminarnim dogovorima poslove suradnje mogla je ugroziti gospodarske interese tvrtke. A i bez dozvole je iz prostorija tvrtke iznijela poslovne dokumente te ih dala na uvid javnosti putem medija.

Vesna Balentović podnijela je kaznenu prijavu protiv nekoliko članova rukovodstva INA-e koja je odbačena, no to je učinila nakon medijskog istupa.

Europski sud utvrdio je da otkazivanje ugovora o radu zbog medijskih istupa predstavlja miješanje u pravo na slobodu izražavanja, kao i da je to miješanje bilo propisano zakonom te da je imalo legitimne ciljeve - zaštitu ugleda i prava drugih, konkretno poslovnog ugleda i interesa INA-e. Iz ovoga je evidentno da je zaštićen ugled ne samo fizičkih već i pravnih osoba, a s obzirom na to da je Sud u svojoj praksi ugled svrstao pod privatnost te mu pružio zaštitu čl. 8. Konvencije, proizlazi da i pravne osobe uživaju zaštitu privatnog života, odnosno da su zaštićene čl. 8. Konvencije. Sud je, odlučujući o tome je li miješanje bilo nužno u demokratskom društvu ili nije, utvrdio da jest te je stoga zahtjev ocijenio nedopuštenim.

Sud je posebno odvagnuo slobodu izražavanja, pravo na javno iznošenje kritika te pravo javnosti da primi informacije od javnog interesa $\mathrm{s}$ jedne strane $\mathrm{u}$ odnosu na zaštitu ugleda i prava drugih. ${ }^{50}$ Iz zaključaka Suda u ovom predmetu iščitava se međunarodni demokratski standard većeg ograničenja slobode izražavanja zaposlenika u odnosu na poslodavca te već spominjani manji opseg ograničenja slobode izražavanja novinara.

"Sud primjećuje da podnositeljica zahtjeva nije bila novinarka - čija je uloga informiranje i skretanje pozornosti javnosti te prenošenje informacija i zamisli o stvarima koje se tiču javnosti - nego zaposlenica koja prema svome poslodavcu ima dužnost lojalnosti, rezerviranosti i diskrecije." 51

U pogledu sredstava korištenih za prenošenje informacija Vesni Balentović svakako nije išlo u prilog to što je, kako je ustvrdio Sud, "koristila sredstva koja imaju širok i trenutni učinak, i to dnevne nacionalne novine velikog opticaja". ${ }^{52}$ Sud je istaknuo u ovom predmetu kako su domaća državna tijela vlasti slobodna donijeti mjere koje predstavljaju primjerenu, a opet ne prekomjernu reakciju na

\footnotetext{
50 Ibid., str. 27.

Ibid., str. 27.

52 Ibid.
} 
neutemeljene klevetničke izjave, kao i one koje su iznesene u zloj vjeri. ${ }^{53}$ Iznimno je bitno, nadodao je Sud, pri tome razlikovati činjenice od vrijednosnih sudova, jer se postojanje činjenica može dokazati, dok postojanje vrijednosnih sudova ne može. Iako i oni, napomenuo je i u ovom predmetu Sud, moraju počivati na dovoljnoj činjeničnoj osnovi.

U konkretnom predmetu Europski je sud ustvrdio da jedan dio izjava Vesne Balentović predstavlja vrijednosne sudove, a drugi činjenične izjave. Ove potonje ista je, prema ocjeni Suda, mogla i trebala dokazati, a nije. Kako su činjenične izjave o kriminalnim radnjama vrlo ozbiljne optužbe, Sud je iskoristio priliku podcrtati još jedan demokratski standard - "što je ozbiljnija 'optužba', to solidniji trebaju biti dokazi". ${ }^{54}$ Iz ovog se predmeta iščitava stav Suda, još jedan međunarodni demokratski standard u pogledu slobode izražavanja - da je pri ocjeni vrlo bitan ne samo sadržaj, već i ton izjava iz čega se može prosuditi motiv iznošenja izjava uvredljivog ili klevetničkog sadržaja.

Postupak u predmetu Radobuljac protiv Hrvatske pokrenuo je Silvano Radobuljac, odvjetnik koji je pri obavljanju svoje profesionalne dužnosti uvrijedio sud te mu je zbog toga izrečena novčana kazna. ${ }^{55}$ Naime, kao branitelj predstavljao je tužitelja u parničnom postupku u kojem je izostao s jednog ročišta zbog čega je sud donio odluku o mirovanju postupka protiv koje je Radobuljac izjavio žalbu. Sporna izjava zbog koje je kažnjen sastavni je dio te žalbe, a glasi: "Naznačeno postupanje suca apsolutno je neprihvatljivo. Na takav način nastoji stvoriti dojam kako postupa u predmetnoj pravnoj stvari, dok se suštinski ročišta održavaju bez smislenog sadržaja". ${ }^{56}$ Novčanu kaznu zbog vrijeđanja suda 2010. izrekao je isti sudac na kojega se izjava odnosila. Povodom žalbe Silvana Radobuljca u srpnju 2010. Županijski sud u Vukovaru istu je odbio potvrdivši odluku prvostupanjskog suda uz obrazloženje da "takve izjave predstavljaju neprihvatljivu komunikaciju između suda i odvjetnika... Te izjave ... prelaze granice uloge odvjetnika u postupku... i mogu se pravno okarakterizirati kao zlouporaba postupka zbog neprimjerenog komuniciranja". ${ }^{57}$

Silvano Radobuljac podnio je u kolovozu 2010. ustavnu tužbu zbog, kako je tvrdio, povrede svoje slobode izražavanja redovnih sudova. Ustavni je sud tužbu odbacio kao neosnovanu. Razmatrajući ovaj predmet, Europski se sud pozvao na međunarodni demokratski standard koji se iskristalizirao u ranijoj sudskoj praksi, da je "članak 10. primjenjiv ne samo na 'informacije' ili 'ideje' koje su blagonaklono

53 O ovom kriteriju detaljnije u predmetu Castells v. Spain, 23. travnja 1992., stavak 46., Series A br. 236., https://www.legislationonline.org.

54 Vidi: Odluka Balentović protiv Hrvatske, str. 28.

55 Radobuljac protiv Hrvatske, Zahtjev br. 51000/11, presuda od 28. lipnja 2016., dostupno na: https://uredzastupnika.gov.hr/UserDocsImages//dokumenti/Presude\%20i\%20odluke//Radobuljac\%20 protiv\%20Hrvatske, \%20presuda.pdf

56 Ibid., str. 3.

57 Ibid., str. 5. 
prihvaćene ili se ne smatraju uvredljivima ili ne izazivaju nikakvu reakciju, nego i na one koje vrijeđaju, šokiraju ili uznemiruju". ${ }^{58}$

Sud je u ovom slučaju utvrdio da je izricanje novčane kazne zbog vrijeđanja suda predstavljalo miješanje u slobodu izražavanja, kao i da je bilo propisano zakonom te se njime težilo ostvarenju legitimnog cilja - održavanju autoriteta sudbene vlasti. Napominjući kako sudove, kao jamce pravde u državi u kojoj je vladavina prava, treba zaštititi od neutemeljenih štetnih napada, Europski se sud u ovom predmetu upustio u utvrđivanje pravedne ravnoteže između potrebe za zaštitom autoriteta sudbene vlasti i zaštite slobode izražavanja. Stoga je proveo 'test nužnosti u demokratskom društvu' utvrđujući je li miješanje u slobodu izražavanja odvjetnika Radobuljca odgovaralo 'snažnoj društvenoj potrebi'. Utvrdio je da nije, a iz njegova se obrazloženja iščitava još jedan međunarodni demokratski standard u pogledu slobode izražavanja, a to je njihov povećan opseg slobode izražavanja u pogledu obavljanja svoje profesionalne dužnosti.

Europski sud je to ovako argumentirao: "Iako su podložni ograničenjima njihovog profesionalnog ponašanja, koje mora biti diskretno, iskreno i dostojanstveno, također uživaju isključiva prava i povlastice koje mogu biti različite ovisno o nadležnosti - među njima je u pravilu i određena sloboda u vezi s tvrdnjama koje se koriste na sudu. Stoga je sloboda izražavanja odvjetnika povezana s neovisnošću pravne struke, što je ključno za učinkovito funkcioniranje poštenog suđenja." ${ }^{59}$

Napominjući da odvjetnici prilikom obrane svojih klijenata ponekad moraju uputiti prigovor na rad suda, Europski sud istaknuo je da to prigovaranje ipak ne smije prijeći određene granice, da treba strogo razlikovati kritiku od uvrede. Pri tom je vrlo bitna namjera. Ukoliko se utvrdi da je jedina namjera odvjetnika bila uvrijediti sud, ne može biti govora o povredi njegove slobode izražavanja u slučaju da mu se zbog toga izrekne kakva sankcija. I ovdje je sud uzeo u obzir sredstvo putem kojeg su izneseni sporni navodi. Činjenica da su isti izneseni u sklopu postupka u kojem su se branila prava klijenta, a ne putem medija, svakako je išla u prilog podnositelju zahtjeva. Europski sud je iz toga, kao i tona i sadržaja izrečenoga, odnosno napisanoga u žalbi, zaključio kako jedina namjera odvjetnika nije bila diskreditirati sud, već zaštititi svoju stranku. Sud je ustanovio kako su domaći sudovi primjedbe podnositelja zahtjeva propustili staviti u kontekst i oblik u kojem su izražena. Zaključak je suda u ovom predmetu da nije bilo snažno prisutne društvene potrebe za ograničenjem slobode izražavanja. Zato je presuđena povreda čl. 10. Konvencije.

Predmet Žugić protiv Hrvatske vrlo je sličan potonjem, s tim da je ovdje presuda bitno drugačija, jer je Europski sud utvrdio kako nema povrede čl. 10. Konvencije. Naime, postupak je pokrenut temeljem zahtjeva Nikole Žugića podnesenog u

58 Ibid., str. 14.

Ovo se načelo iščitava i iz predmeta Kubli protiv Švicarske (odl.), br. 50364/99, 21. veljače 2002., https://uredzastupnika.gov.hr

59 Ibid., str. 17. 
siječnju 2008.$^{60}$ On se, zbog ovršnog postupka pokrenutog protiv njega, našao u sudskom postupku pred Općinskim sudom u Zagrebu. Kao pravnik po struci, mada ne odvjetnik, odlučio je sam sebe zastupati. U žalbi protiv prvostupanjske presude uloženoj u prosincu 2005. Županijskom je sudu u Zagrebu, između ostaloga, napisao: "Indikativno je ovdje napomenuti da je sutkinja prije diktata izreke presude upitala tuženog hoće li 'ovo platiti', a na što je tuženik odgovorio 'što vam pada na pamet?, i je li ona proučila spis... Sutkinja se ljutito okrenula sa stolice na bok i zapisničarki izdiktirala izreku presude u ime $\mathrm{RH}$, navodeći komičan izraz da stranke traže obrazloženje presude - kao da u kontradiktornom postupku postoje presude bez obrazloženja ili pouke o pravnom lijeku. Nažalost, ove dijaloge sutkinje i tuženoga, sud nije unio u zapisnik. Kakva li je ovo sudačka profesionalnost!" ${ }^{1}$

Prvostupanjski je sud utvrdio da je tuženik uvrijedio ne samo sud kao instituciju, već i sutkinju kao osobu. Županijski sud usuglasio se s prvostupanjskim sudom pa je odbio žalbu Nikole Žugića te u travnju 2007. potvrdio prvostupanjsku odluku. U srpnju 2007. Nikola Žugić podnio je ustavnu tužbu koju je Ustavni sud ocijenio nedopuštenom.

Postupajući u ovom predmetu, Europski sud ponovio je većinu onoga što je već navedeno u sklopu analize presude Radobuljac protiv Hrvatske. I ovdje se, ocijenivši prethodno da je došlo do miješanja u slobodu izražavanja i to temeljem zakona poradi zaštite ugleda i prava drugih, Sud upustio u razmatranje je li to bilo 'nužno u demokratskom društvu', odnosno je li odgovaralo 'snažno prisutnoj društvenoj potrebi'. Pri tom je, kao i kod prethodno analiziranog predmeta, utvrđivao je li miješanje 'razmjerno legitimnom cilju koji se teži ostvariti' te jesu li razlozi kojima državni organi vlasti pravdaju to miješanje 'mjerodavni i dostatni'.

Temeljem svoje ranije prakse, Europski je sud u ovom slučaju utvrdio kako je jedina namjera podnositelja zahtjeva bila uvrijediti sud, a izjave su bile izrečene na 'omalovažavajući i drzak način' te nisu bile samo kritika presude i načina vođenja postupka, o čemu se radilo kod predmeta Radobuljac protiv Hrvatske, već su bili uvreda na račun osobe sutkinje, implicirale su da je ona "nesposobna neznalica". ${ }^{62}$ Sud je stoga smatrao da su razlozi domaćih sudova 'mjerodavni i dostatni', a novčana kazna izrečena podnositelju zahtjeva razmjerna legitimnom cilju - zaštiti autoriteta sudbene vlasti. Zaključeno je stoga da nije došlo do povrede čl. 10. Konvencije, iako su tri suca (Spielmann, Hajiyev i Nicolaou) dali izdvojeno mišljenje. Oni su smatrali da je došlo do povrede čl. 10. Konvencije jer je podnositelj zahtjeva "samo opisao, iako snažnim riječima, što se događalo u raspravi". Nisu se složili s činjenicama te

60 Žugić protiv Hrvatske, Zahtjev br. 3699/08, presuda od 31. svibnja, 2011., dostupno na: https:// uredzastupnika.gov.hr/UserDocsImages//arhiva//ZUGIC,.pdf

61 Vidi: Presuda Žugić protiv Hrvatske, str. 3.

62 Vidi: Mahler protiv Njemačke, br. 29045/95, odluka Komisije od 14. siječnja 1998. gdje je odvjetnik tvrdio da je državni odvjetnik 'sastavio optužnicu u stanju potpunog otrovanja'. W. R. protiv Austrije, br. 26602/95, odluka Komisije od 30. lipnja 1997. kada je branitelj mišljenje suca nazvao 'komičnim' te Saday protiv Turske, br. 32458/96, 30. ožujka 2006., kada je okrivljenik za tursko sudstvo rekao da su 'mučitelji u odorama' (https://uredzastupnika.gov.hr). 
su zaključili kako izjave podnositelja žalbe nisu uvredljive pa stoga razlozi kojima su domaći sudovi argumentirali svoje odluke nisu mjerodavni ni dostatni.

Iz razmimoilaženja sudaca u pogledu ocjene u ovom predmetu jasno je koliko u praksi zaista nije laka procjena je li ili nije povrijeđena sloboda izražavanja. Očigledno, većina je sudaca utvrdila da međunarodni demokratski standard prema kojem izjave izrečene isključivo $s$ namjerom da naruše ugled osobe, zajedno s nužnom zaštitom autoriteta sudbene vlasti, u ovom predmetu nalažu izuzimanje od zaštite. Drugi suci su, vodeći se istim demokratskim standardom, zaključili da su odvjetnikove izjave imale u vidu interes branjenika, odnosno pravičnog suđenja. Međutim, njihova argumentacija neslaganja ulazi već u činjenično stanje predmeta što Europski sud vrlo rijetko preispituje. Utvrđivanje činjenica, kako je već rečeno, osim u iznimnim slučajevima, prepušteno je državnim tijelima.

\section{RESTRICTIONS ON FREEDOM OF EXPRESSION IN THE REPUBLIC OF CROATIA IN RELATION TO INTERNATIONAL LAW, WITH SPECIAL REFERENCE TO JUDGMENTS OF THE EUROPEAN COURT}

Freedom of expression is without a doubt one of the cornerstones of democracy. Its legal nature is complex, given that it is both a derivative and a legal construction. Namely, freedom of expression is one of the derivatives of freedom as a fundamental value of modern legal systems based, clearly, on international human rights law. And while freedom is an absolute category, freedom of expression and some other rights are not.

Key words: freedom of expression, restrictions, European Court of Human Rights, judgments, Republic of Croatia 